\title{
Only One Oar in the Water: The Political Failure of School Desegregation in Yonkers, New York
}

\section{Citation}

Failer, Judith L., Anna Harvey, and Jennifer L. Hochschild. 1993. Only one oar in the water: The political failure of school desegregation in Yonkers, New York. Educational Policy 7(3): 276-296.

\section{Published Version}

http://dx.doi.org/10.1177/0895904893007003003

\section{Permanent link}

http://nrs.harvard.edu/urn-3:HUL.InstRepos:3427432

\section{Terms of Use}

This article was downloaded from Harvard University's DASH repository, and is made available under the terms and conditions applicable to Other Posted Material, as set forth at http:// nrs.harvard.edu/urn-3:HUL.InstRepos:dash.current.terms-of-use\#LAA

\section{Share Your Story}

The Harvard community has made this article openly available.

Please share how this access benefits you. Submit a story.

Accessibility 
ONE OAR IN THE WATER:

THE POLITICAL FAILURE OF SCHOOL DESEGREGATION IN YONKERS, NEW YORK

\author{
Judith L. Failer \\ Department of Politics \\ Princeton University \\ Princeton NJ 08544 \\ 609-924-5105; fax: 609-258-4772 \\ e-mail: jlfailer@pucc.princeton.edu \\ Anna Harvey \\ Department of Politics \\ Princeton University \\ Princeton NJ 08544 \\ 609-258-1854; fax: 609-258-1985 \\ e-mail: alharvey@pucc.princeton.edu \\ Jennifer Hochschild \\ Department of Politics \\ Princeton University \\ Princeton NJ 08544 \\ 609-258-5634; fax: 609-258-1985 \\ e-mail: hochschi@pucc.princeton.edu
}

Please direct all correspondence to Jennifer Hochschild, Department of Politics, Princeton University, Princeton, NJ 08544 


\section{BIOGRAPHICAL STATEMENTS}

Judith Failer is a graduate student in the Department of Politics at Princeton University, and will join Indiana University as Lecturer in Political Science in Fall 1993. She received her B.A. from Wesleyan University in 1986 and her M.A. from Princeton University in 1989.

Anna Harvey is a graduate student in the Department of Politics at Princeton University. She received her B.A. from the Honors Tutorial College of Ohio University in 1988 and her M.A. from Princeton University in 1990.

Jennifer Hochschild is Professor of Politics and Public Affairs, Princeton University. Hochschild received her B.A. from Oberlin College in 1971 and her Ph. D. in Political Science from Yale University in 1979. She is the author of What's Fair: American Beliefs About Distributive Justice (Harvard, 1981); The New American Dilemma: Liberal Democracy and School Desegregation (Yale, 1984); and Equalities (co-author; Harvard, 1981). She has served as a consultant or expert witness in school desegregation cases in Yonkers, Denver, Chicago, San Francisco, Hartford, and the State of New Jersey.

ACKNOWLEDGMENTS: This work benefits from the research of Steven J. Routh, Lawrence Thomas, and Monica Herk. They have our deep thanks, as does Mwalimu Shujaa for his heroic editing. 


\begin{abstract}
Political efforts to desegregate public schools do not fail solely because of political opposition. They fail when political opposition joins and interacts with an institutional structure that ambiguously divides educational authority between state and local actors. Both factors--a high level of political controversy and a shared system of educational authority--were present in Yonkers, New York during the 1960s and 1970s, and combine to explain the district's failure to desegregate its schools. Using a "regression by hand," the authors show that neither factor taken alone necessarily undermines a policy's success in the political arena. The political success of New York's policy to fund non-public schools demonstrates that controversial policies can be realized when the institutional structure that creates them does not divide authority between state and local actors. Conversely, the political success of efforts to reform Yonkers' programs in special education shows that shared responsibility can promote educational reform if the policy is not controversial. The authors conclude by cautioning against abandoning efforts to desegregate public schools, and call for changes in the structure of shared state and local responsibility for educational policy.
\end{abstract}


Nearly forty years after Brown $\underline{\mathrm{v}}$. Board of Education (1954), advocates of school desegregation face a disheartening landscape. Although racial isolation in schools declined sharply in the South between 1964 and 1972 and has decreased gradually in the border, midwestern, and western regions between 1964 and 1989, segregation in public schools has since increased in the South and has consistently risen in the Northeast. In fact, the Northeast is now the region of the United States where black and Latino students are the most racially segregated, with $70 \%$ of urban black students in schools that enroll between 90-100\% blacks and Latinos (Boozer et al., 1992).

Desegregation's limited success (and failure in the Northeast) has led many former proponents of integrated education to doubt whether desegregation will ever secure equal educational opportunity for students of all races. Consequently, many educators now seek to enhance the quality of education for black and Latino students by improving, and sometimes fostering, racially isolated schools. While we share these doubts, we are not yet ready to give up on desegregation. Racially isolated schools cannot provide the advantages of integrated education in the classroom, playground, and eventually workplace. Black students who attend desegregated schools complete more years of schooling, are more likely to work in white-collar and professional jobs, obtain jobs in more integrated firms, and receive higher wages than black students who attend racially isolated schools (Boozer et al., 1992; Crain et al., 1985). Furthermore, the participants themselves endorse school desegregation; since 1983, more than half of first-year college students of both races have supported the use of busing to achieve racial balance in schools (Cooperative Institutional Research Program 1992; Cooperative Institutional Research Program 1987).

These findings make urgent the need to account for the failure of desegregation in the Northeast. In this article we examine the political reasons for the failure to desegregate schools in New York State. Specifically, we analyze why the public officials responsible for education in New York failed to develop and implement a policy to desegregate Yonkers (a failure recently remedied in United States $\underline{v}$. Yonkers Board of Education (1985)). Particularly now that courts are more willing to relinquish responsibility for desegregation to legislative and executive authorities (Greenhouse, 1992), the need to understand why this policy is so politically vulnerable, and to suggest how it might be made less so, is of pressing importance.

\section{THE POLITICAL FAILURE OF DESEGREGATION}

\section{A. Political Controversy and Desegregation}

Analysts of the political failure of desegregation typically point to the policy's two most controversial aspects. First, desegregation apparently imposes a transfer of resources from a majority of people (better-off whites with children in the better public schools) to a minority of people (worse-off blacks [and sometimes Latinos] with children in worse public schools). Second, the predictable political conflict generated by downward redistribution is often exacerbated by whites' racially based opposition to desegregation. A policy that challenges both economic and social dominance will be so controversial, the argument goes, that the white majority will be able to shut down integrative actions (Wilson, 1974).

However, political controversy alone cannot account for the failure of desegregation in New York State. The socially and economically redistributive effects of other educational policies also generated strong political opposition, yet those policies were successfully developed and implemented. Case studies demonstrate that the State's and local school boards' shared responsibility for public education also affects the political viability of a policy proposal. That is, the combination of 
majority opposition to desegregation and shared institutional responsibility made desegregation politically impossible, whereas similar opposition absent shared institutional responsibility allowed other controversial policies to enjoy political success.

\section{B. The Structure of Educational Authority and Desegregation}

As in most states, local school districts carry out the day-to-day administration of education in New York. However, state-level actors in New York have historically had an unusually important role in developing and overseeing implementation of educational policy (Murphy, 1974; Milstein et al., 1973, Usdan, 1963). Many scholars believe that the State's prominent and professionalized role in public education has enhanced educational quality and equity in New York. In particular, the State's relatively centralized and politically insulated educational structure has been assumed to facilitate implementation of controversial policies such as desegregation (Hochschild, 1984).

If state educational institutions were insulated from local controversy, that might be the case. In fact, localities share educational authority with state actors in New York more than do localities in other states. That is, state educational actors and local school boards in New York have increasingly functioned as institutional partners in developing and implementing policy for public education. The terms of this State-local institutional partnership, broadly defined in New York's Constitution and in statutory law, provide that 1) the Board of Regents promulgates educational policy, 2) the State Education Department (SED) and its Commissioner translate these policies into operational regulations, and 3) local school districts, as agents of the SED, implement them under the SED's oversight (N.Y. Const.; N.Y. Educ. Law; N.Y.C.R.R.).

The law does not always specify where the State's responsibility for an educational matter ends and the local districts' responsibilities begin, however. And where the law does not clearly delineate specific duties but does require that certain goals be met, the degree of harmony in the state-local partnership varies with the political context. Where the political will exists, both institutional partners may take actions even beyond those legally required of them in order to fulfill shared goals. But where political will is lacking, the partners may refuse or be reluctant to take actions not legally required of them, may drag their feet on their mandated duties, and may impede the other's ability to carry out its share of their joint functions. As we shall demonstrate, a less than harmonious partnership played an important role in frustrating policies to desegregate schools in New York.

But, just as political controversy alone cannot derail a proposed educational policy, so shared institutional responsibility does not suffice to explain the political failure of a proposed policy. Many new policies have been pursued successfully within New York's educational structure. Rather, it was the combination of high levels of controversy and shared institutional responsibility for public education which frustrated New York's policy for desegregation. That frustration occurred in two distinct ways. First, political controversy and institutional structure joined to prevent immediate implementation of desegregation in the early 1960s. Second, the two variables interacted to create a see-saw dynamic of action and inaction by state and local actors which effectively stymied later efforts by localities such as Yonkers to desegregate their schools.

After presenting our theory of the joint and interactive effects of political controversy and institutional structure, we will illustrate how this framework can help explain the political failure of efforts to desegregate Yonkers. We begin our "regression by hand" by describing the history of desegregation in Yonkers. That history shows how both State and local actors' obstruction of 
desegregation in the 1960s, and their interactive dynamic of action and inaction in the 1970s, combined to frustrate attempts to desegregate Yonkers. We then turn to two case studies of politically successful educational policies in New York. They demonstrate that the presence of either factor--controversy or shared responsiblity--was not enough to block the policy process.

The first case, the provision of state aid to non-public schools (parochaid) in the early 1970s, resembled desegregation in that it also generated extensive opposition to its economic redistribution to a disfavored minority. Yet it differed from desegregation in that it was developed in a unified political structure which made local opposition ineffectual. Thus parochaid's political success shows that controversy alone need not impede political action by the State.

The second case, the restructuring of Yonkers' program in special education, resembled desegregation in that both policies had to be negotiated within the structure of New York's shared institutional responsibility for public education. Yet, unlike desegregation, special education was not perceived as redistributing resources to a disfavored minority, and therefore did not generate great political controversy. Thus its eventual political success shows that a shared institutional structure alone does not necessarily thwart the policy process.

We conclude by examining the implications of our argument both for Yonkers and for the political prospects of desegregation more generally.

\section{The Political Failure of Desegregation in New York}

Political controversy can combine with shared institutional responsibility for educational policy to affect a policy's political chances in two ways. First, the two variables can join to impede implementation. In a partnership where one majority-controlled partner would bear all the direct "costs" of a new and controversial policy, that actor has strong incentives to fight the change by refusing to develop and implement it. Unless the second partner has very strong incentives to pursue the policy (strong enough to overcome the costs of doing more than its normal share of the work), the policy will fail.

In New York, local school boards (dominated by white parents and business elites) saw themselves as bearing all of the social and economic costs of desegregating, while state actors disagreed with one another about the political payoffs which desegregation might bring. Localities thus had stronger incentives to resist implementation than the State had to enforce it. Predictably, many localities thwarted desegregation policy throughout the 1960s.

The joint effects of controversy and shared authority do not, however, explain why desegregation failed in Yonkers. Twice school officials became willing partners and tried to join with the State to desegregate Yonkers' schools. Why, when a previously unwilling partner became willing to shoulder its share of the responsibility, did the policy still fail? The answer lies in the interaction of political controversy and institutional structure in New York over time.

This interaction was enabled by the fact that the division of educational authority between the State and the localities in New York is only broadly delineated and is thus subject to the influence of the political context. The Commissioner's ability to define the terms of the State-local partnership itself depends on how much the rest of the State government supports a given policy. The less unified the State's support, the less the Commissioner can claim to speak for "the State" and the less political latitude he has to make his assignment of specific responsibilities stick.

The school boards' status as institutional partners in public education enabled them not only to resist immediate implementation of desegregation, but also to fragment the State's political resolve and capacity to pursue this policy over time. Following the Commissioner's failed attempts 
to desegregate schools in the early 1960s, local boards provided an institutional context within which desegregation's opponents could continue to attract media attention to their refusal to cooperate with the State, thereby ensuring their political visibility to state Legislators. Responding to the publicity generated by the protesting school boards, the Legislature eventually circumscribed the Commissioner's authority to set policies for desegregation. In effect the (in)actions of the resisting school boards transformed the State itself into a reluctant partner, so that when active support for desegregation coalesced in localities for various idiosyncratic reasons, the State passively (and sometimes actively) frustrated desegregation through its inaction. In this rowboat, only one oar was ever in the water at a time, and it never reached the shore.

\section{THE POLITICAL FAILURE OF DESEGREGATION IN YONKERS}

Twice very able local political and educational leaders in Yonkers were poised to desegregate the district. Twice they failed. Although the persistence of local (mainly white) opposition clearly helped to derail these efforts, the failures remain difficult to explain until examined in the context of state-wide battles over desegregation fought primarily in Albany and in other districts. From this broader perspective, the persistence of segregated schools in Yonkers illustrates how political controversy and shared educational authority joined and interacted to set off a chain reaction of moves and counter-moves by the district and the State that derailed desegregation.

This chain reaction occurred in four stages. First, the Commissioner of Education directed all school districts to formulate plans for desegregating racially imbalanced schools. Second, many districts delayed responding to the State's directive, drew substantial media attention to their delaying tactics, and pressured their state legislators to undermine the SED's efforts. Third, legislators responded to their most politically effective constituents by weakening the State's capacity to implement relevant policies. Fourth, when Yonkers was finally ready to desegregate its schools, the State lacked the capacity to help. Without the State's financial and technical support, Yonkers could not overcome local opposition and desegregate its schools.

At any given moment in this history, New York's structure of shared educational responsibilities enabled opponents of desegregation to impede immediate action. In addition, opponents actually altered the terms of the State's and localities' partnership over time, creating a climate that made reductions of racial imbalance increasingly unlikely even when supporters of desegregation gained control of one of the institutional partners.

\section{A. Yonkers' Segregation}

In 1985, a federal district court found Yonkers' Board of Education guilty of intentional discrimination in its schools (United States v. Yonkers, 1985). Although some Yonkers schools were segregated as early as 1961, racial balance had never been much of an issue until the late 1960s when whites began to move out of and minorities began to move into the city, changing the demographics of the public schools (United States $\mathrm{v}$. Yonkers, 1985). Because the new minorities settled in racially secluded neighborhoods, these demographic changes reinforced the racial separation already present in Yonkers' schools. By 1980, segregation was manifest in the racial patterns of student enrollment and faculty and staff assignments, as well as in the distinctly inferior physical plants for black and Latino schools (United States v. Yonkers, 1985).

B. Yonkers' Failure to Desegregate 
1. STATE ACTION. When Commissioner James Allen, Jr. first called for an end to segregation in New York's schools in 1960 (University of the State of New York, 1960), the State's Education Law specified neither his nor the districts' role in ensuring racial balance. Following the findings in Brown, the Regents concluded on January 28, 1960 that segregated schools "damage the personality of minority group children" and "decrease their motivation and thus impair their ability to learn" (University of the State of New York, 1960). But the Regents did not allocate specific responsbilities between the SED and the local districts for identifying imbalanced schools or for remedying the imbalances.

Lacking guidance from New York's Education Law, Commissioner Allen began himself to define the roles of the State and localities. In 1960 he asked each district to begin eliminating segregation in its schools (University of the State of New York, 1960), and in 1961 he announced a racial census of every school "as the first step in a planned attack on segregation." In early 1963, Commissioner Allen directed each district with "racially imbalanced" schools to inform the State by September of how it planned to achieve racial balance. The same day, the Commissioner also responded to a "310" petition (an official complaint) filed the previous year by the NAACP in Long Island's Malverne School District (Matter of Mitchell, 1963). His ruling required Malverne to desegregate an elementary school enrolling $75 \%$ black children. It was the first time any Commissioner in New York had required a local district to desegregate a school.

2. LOCAL RESISTANCE. (Mainly white) citizens and school boards in many districts were appalled both with the "310" order in Malverne and with the Commissioner's directive on racially imbalanced schools. As the direct targets of a proposed downward redistribution of economic resources and equalization of heretofore unequal racial statuses, these local actors had strong incentives to make their concerns heard. By resisting the Commissioner's efforts, local school boards sought to ensure that the majority of citizens did not lose (as they saw it) resources and status in the effort to equalize education for poor and racially subordinated children. Their resistance took several forms.

First, citizens formed pressure groups to protest the Commissioner's efforts to integrate their schools. Second, many school boards responded to protestors by refusing to implement Commissioner Allen's orders and by legally challenging his authority to issue such directives. Although it was eventually overruled, one trial court did hold that the Commissioner lacked authority to force Malverne to desegregate. Other districts began to cite the litigation as a reason to delay compliance with the Commissioner's directives in their own districts (Vetere $\underline{\mathrm{v}}$. Mitchell, 1963). Third, the press covered extensively the politics of desegregation, thereby magnifying the impact of the majority's resistance and the boards' inactions.

In these and other ways, local school boards effectively resisted desegregation. As the partner most directly affected by the policy, they had the incentives and the ability to refuse the State the cooperation necessary for the policy's success ("Allen Directive," 1963).

3. A WEAKENED STATE. The school boards' (in)actions went beyond preventing the immediate implementation of desegregation. They also led to the redefinition of the terms of statelocal partnership in education policy. Previously neutral on the issue of integrated schools, legislators began to react to the potent combination of constituents' protests, districts' defiance of the SED, and the subsequent media circus. Their reactions, over time, diminished the SED's capacity to effect desegregation.

The legislative battle against desegregation began soon after Commissioner Allen issued his 1963 directive. Citing constituents' wishes, legislators had by March 1964 introduced five bills in opposition to busing and any other compulsory measure to effect racial balance. Between 1965 and 
1969, legislators introduced 45 more such bills. In 1969, one anti-busing bill passed, becoming Chapter 342 of the State Education Law (a federal court later found the law unconstitutional) (Lee v. Nyquist, 1970). Legislators from districts with segregated schools also joined forces with longterm advocates of local rule in sponsoring bills to limit the scope of--and in one case, abolish--the Commissioner's powers, and to create an office of Inspector General to review the Commissioner's "310" decisions.

Although few of these bills became law, they fostered a legislative atmosphere that was suspicious of the Commissioner and the SED. Consequently, when Commissioner Allen began to pursue a state-wide Master Plan for integrated education in 1967, the Legislature refused to provide the SED with enough money to enact the Plan's measures. It underfunded the SED's Division of Intercultural Relations (DIR), the office that administered the Department's policies regarding integration and provided technical assistance to desegregating districts. It underfunded and later canceled the State's Racial Balance Fund, money earmarked for helping school districts to create and implement programs for achieving racial balance. Lacking sufficient funds and the capacity to claim that "the State" was behind his policies, the new Commissioner, Ewald Nyquist, could by 1970 no longer battle effectively for desegregation on a state-wide basis. He was reduced to pursuing integration through his "310" power, and even limited that power to occasions when a district or someone in it filed an official complaint.

Still frustrated that the Commissioner continued to use his "310" power to pursue a policy opposed by a conspicuous majority of their constituents, legislators began to pressure the Board of Regents. Some legislators sent letters to the Regents, begging them to stop the Commissioner from intervening in particular districts. Others called on the Regents to fire Commissioner Nyquist. Legislators even began to use an anti-busing "litmus test" when interviewing prospective Regents (Clark, 1988).

These efforts were ultimately successful. After several years, the Legislature had eliminated most supporters of active policies to mandate desegregation from the Board of Regents and had replaced them with strong opponents of busing and other mandatory desegregative techniques. In 1976, a majority of the Board of Regents voted to fire Commissioner Nyquist.

Recognizing that the Legislature and the new Regents posed a formidable barrier to mandated desegregation, the next Commissioner, Gordon Ambach, no longer pursued the goal of integrated schools and issued no "310" rulings ordering schools to desegregate. Now both partners lacked incentives to pursue the policy.

4. LOCAL INACTION. While the State was becoming less willing and able to help local districts achieve racial balance, Yonkers was becoming more segregated. Within Yonkers, citizens and municipal officials disagreed on what to do about their segregated schools. Some (mainly black) parents wrote letters to the SED complaining of racial tension and imbalance; others (mainly white) formed protest groups similar to those in Malverne or altered the mission of extant neighborhood groups to oppose any school reorganization plan that involved busing.

Despite widespread white opposition to and considerable black ambivalence about integration, there were at least two times when local educational leaders were willing to cooperate with the State to desegregate Yonkers' schools. The first time occurred in the late 1960s and early 1970 when Superintendent Paul Mitchell took steps toward improving the racial balance in Yonkers. He planned to open two racially integrated schools and to hire black staff, and he designed workshops to help personnel meet the distinctive needs of black students (United States $\underline{\mathrm{v}}$. Yonkers, 1985). He sought technical aid from the DIR and money from the Racial Balance Fund. Before the State could proffer its limited help, however, Superintendent Mitchell died suddenly in 1970. 
Lacking both Superintendent Mitchell's commitment to integration and the State's commitment to supplemental funding, the school board's efforts to desegregate Yonkers ceased. Acting Superintendent James Gallagher later justified his reluctance to pursue Superintendent Mitchell's plans for desegregation through the community's resistance to desegregation. In its increasingly weakened position, the SED did not push Superintendent Gallagher to change his mind. Legislators had just eliminated the Racial Balance Fund, and the DIR was stymied by local opponents whom Superintendent Mitchell had known how to appease (United States $\underline{\mathrm{v}}$. Yonkers, 1985). Without State or local leadership, the momentum from Superintendent Mitchell's efforts dissolved.

Almost a decade later, Superintendent Joseph Robitaille made the next major effort to desegregate Yonkers' schools. A severe budget crisis combined with declining enrollments to make school closings seem essential, and school closings required redistricting. To Superintendent Robitaille, a majority of the school board, and a newly-energized NAACP, this was an excellent opportunity to improve racial balance as well. Despite opposition from the Mayor and many white citizens, Superintendent Robitaille issued his "Phase II" reorganization plan on August 5, 1977.

Yonkers, however, was in the midst of a city-wide financial crisis, and could not pay for desegregation on its own (Robitaille, 1990). DIR officials promised technical assistance and came close to promising state funds to help develop and implement "Phase II." But the now deeplyweakened SED provided no technical assistance and delayed providing funds, and opponents to desegregation became deeply entrenched. By the time the SED informed Yonkers that it could provide no additional money, Mayor Antonio Martinelli had replaced the most active and liberal school board members with conservatives who refused to support programs that would destroy "the tradition of neighborhood schools" (Guerney, 1990). After all, as one neighborhood organization observed, why pursue an unpopular program when "there is very little likelihood that the Commissioner [Ambach] would mandate a forced busing program on the city of Yonkers" (TONEY, 1977; see also Lincoln Park Taxpayers, 1977).

The loss of the apparently-promised State money felt like the SED had "literally abandoned us and we found ourselves in the soup," according to one former school board member (Jacobson, 1990). The following spring, the board adopted the only two components of "Phase II" it ever considered: reorganizing the grade structure and transforming one middle school into a school for vocational education. Neither action affected racial balance and Superintendent Robitaille realized that the School Board would never act on this part of his plan. Six months later, he resigned.

In 1980, the local chapter of the NAACP joined with the U.S. Department of Justice to sue the Board of Education and the City of Yonkers for allowing discriminatory schools to persist. After another five years, a federal court found intentional segregation in the schools.

Clearly, shared state and local institutional responsibilities for public education allowed local actors' opposition to desegregation to delay or prevent implementation of a mandated state policy. But the joint effects of (local) controversy and shared (state and local) institutional responsibility tell only part of the story. The interaction of the two factors over time is equally important.

More precisely, the shared responsibilities for public education in New York enabled local opponents of desegregation, through the widely-publicized warfare between the protesting boards and the Commisioner, substantially to raise the costs to legislators of pursuing the policy. Because the shared responsiblities for desegregation were not precisely defined, the Legislature could curtail the Commissioner's authority and the DIR's resources to act in the state-local partnership, thus rendering the State an unwilling or ineffectual partner. Once the Legislature had weakened the 
State's role in the institutional partnership, the State could no longer help to desegregate communities such as Yonkers, even when local supporters of desegregation got the upper hand. Thus the mutually reinforcing dynamic of action and inaction in Yonkers--the zig-zag movements of a rowboat in which only one oar is in the water at a time--resulted from the interaction of political controversy and a particular governmental structure.

\section{THE POLITICAL SUCCESS OF PAROCHAID: INEFFECTIVE CONTROVERSY}

Parochaid (state aid to non-public schools) in the early 1970s generated similar kinds and levels of political controversy as did school desegregation. Both policies would have involved downward redistribution of scarce educational resources from a wealthier majority to a poorer minority. Both would also have benefited a socially stigmatized minority (in the case of parochaid, predominantly Catholic parochial students). And in both cases local school boards led the opposition to the State's policy, since they were the institutional actors that would bear the brunt of the financial and social costs of the new policy.

Here the similarities end. In the case of desegregation, local school boards could delay implementing the policy until the Legislature diminished the State's willingness and capacity to act. In the case of parochaid, however, local opponents could not prevent the Legislature, in cooperation with the Governor, Regents, and the SED, from pursuing the policy.

Why not? Because parochaid was by definition a matter of private rather than public education. The policy was therefore developed within an institutional structure--budgetary politics-that involved only State actors; local school boards had no role in effecting the policy. They were simply out of the loop.

As outsiders, local opponents to parochaid lacked both the direct and the indirect levers of protest they enjoyed as members of the educational partnership that controlled desegregation. Without a direct institutionalized voice, they could not delay implementing parochaid by refusing to cooperate with State actors. Their cooperation was irrelevant to the policy's successful enactment and implementation. In addition, school boards and citizen groups had no arena for the dramatic acts of resistance which garnered so much media attention in the case of desegregation, so they were less able to push the Legislature into the role of spoiler. Thus they also had little indirect control over the policy. As a result, local opponents of parochaid, despite constituting a majority of voters, were forced to stand by as the State's educational policy-makers handed over precious state funds to a relatively poor and socially disfavored minority.

Parochaid first became a political hot potato during the State Constitutional Convention of 1967. Proponents of parochaid seized the occasion to repeal the Blaine Amendment, the State's constitutional ban on the use of state monies "either directly or indirectly" to aid schools controlled "wholly or in part" by religious organizations. Effective campaigning by Catholic interest groups had ensured the election of many convention delegates who were Catholic or who for other reasons supported repeal (Hacker, 1967). Moreover, the Church had successfully lobbied for the support of Commissioner Allen, the Board of Regents, the Governor, and prominent legislators (Kihss, 1966).

Repeal passed the Convention with a bipartisan vote of 132-49.

Despite the State's unified stand, parochaid remained politically volatile and unpopular. Realizing that they had been outmaneuvered by Catholic interest groups during the Convention, opponents to parochaid mobilized to prevent ratification of the proposed Constitution in 1967. Interest groups representing public education and civil liberties, including the powerful New York State Educational Conference Board, the United Federation of Teachers (UFT), the United Parents 
Association, and Jewish and Protestant organizations (Kihss, 1966), formed an umbrella lobbying group in early 1967 called Public Education And Religious Liberty (PEARL) to oppose ratification (Spiegel, 1967).

During the 1967 ratification campaign, these opponents argued that parochaid would unfairly shift educational resources from the public schools (which enrolled $80 \%$ of New York's elementary and secondary students) to the non-public schools (which enrolled the other 20\%). Since the State had refused to increase aid to public schools, citing increasingly severe budgetary constraints, and since taxpayers in many school districts had recently rejected increases in local property taxes, opponents argued that subsidizing the non-public schools would draw money and talented students away from the public schools ("Sutton and Cardino," 1967; Farber, 1967; Ronan, 1967; Schumach, 1967). Anti-Catholic sentiment further infused the controversy, particularly after Jewish and Protestant organizations joined the parochaid opposition. That sentiment led William J. Vanden Heuvel, Fourth Vice President of the Constitutional Convention, to condemn the "latent religious antagonisms" aroused during the ratification campaign (Schanberg, November 9, 1967).

The campaign for ratification was "dominated by an emotional fight over the church-state issue," and heavy turnout defeated the proposed Constitution by a margin of 3 to 1 (Schanberg, November 8, 1967). Yet even after this conclusive rejection of the policy, legislators of both parties, supported by Governor Rockefeller and the Board of Regents, pledged to introduce a constitutional amendment to repeal the ban on parochaid in the next legislative session ("Salvaging the Good," 1967). Under pressure from Catholic organizations, the Senate's leadership introduced legislation to repeal the Blaine amendment in 1968, which passed 35 to 17. However, to amend the Constitution, both houses of the Legislature would have to pass the bill in two successive years. The State's voters would then need to ratify it in a referendum. Leaders of the Assembly were sufficiently concerned about the recent electoral defeat of the proposed Constitution that they did not introduce a repeal bill in 1968 or in 1969 (Flast et al., 1968; Ronan, 1968; Schanberg, 1968). But in 1970, both the Senate and the Assembly passed two repeal bills, either of which could be passed again in the 1971 session in preparation for ratification.

By this time, however, leading proponents of parochaid doubted whether the repeal would survive a state-wide referendum. Although advocates had downplayed the importance of opposition to parochaid in the defeat of the 1967 Constitution, an increasing number privately acknowledged that they lacked the electorate's support. The Church therefore decided in 1970 to pursue indirect state aid to parochial schools through state budgetary politics rather than through a constitutional amendment (which would again put parochaid to the voters) (Lynn, January 1971).

The budgetary push for state aid to non-public schools was successful. Between 1970 and 1972, the Legislature approved assistance to non-public schools for State-mandated services (such as testing, record-keeping, and building maintenance) as well as direct tuition grants and tax abatements for the parents of students in parochial schools. Three different bills, all with the support of the State's leading educational policy-makers, allocated 117 million dollars to New York's non-public schools during this period (Clines, February 1970; Clines, April 1970; Lynn, 1970; Spiegel, January 1970; Spiegel, June 1970; Farrell, 1971; Dugan, 1972; Lubasch, 1972; Narvaez, 1972).

Opponents of parochaid now faced a grim political situation. Despite the opposition of a majority of New York's voters to parochaid, opponents could not make their opposition effective once the battle was removed to the arena of budget-making. They could no longer vote down a proposed Constitutional amendment. Furthermore, since budgetary politics was dominated by organized interest groups such as the Catholic Church and other private school organizations, local 
school boards and private citizens had no legitimated role in allocating funds. Lacking means to resist the policy change, opponents could not transfer the costs they were incurring to legislators or other State officials. Without serious electoral costs, and with strong incentives provided by interest groups, State actors continued to fund private schools.

With no political alternatives available, opponents of parochaid turned to the judicial system. In 1971, the U.S. Supreme Court held that state aid to religious schools for the purposes of "secular education services" was unconstitutional. The next year, a federal district court barred New York from disbursing the 33 million dollars it had allocated for such services before the Supreme Court announced its decision (Farrell, 1972; Graham, 1971). Also in 1972, the District Court found unconstitutional the annual 28 million dollars of parochaid appropriated in the 1970 Mandated Services Act and the 1972 law that allocated money to non-publics for building maintenance and tuition grants. It barred the SED from disbursing any more of these funds (Graham, 1972; Sibley, 1972).

The State appealed these rulings to the U.S. Supreme Court. In 1973, the Court found that all four methods of indirect state aid to parochial schools violated the First Amendment (Peterson, 1973). But the State persisted. The following year the new Governor, Malcolm Wilson, requested and received legislative approval for a bill to reimburse parochial schools for the actual costs of State-mandated services, up to 10 million annually (Greenhouse, 1974). A U.S. Appeals Court found this version of parochaid unconstitutional as well in 1976 ("Parochial School Aid," 1976). After 1976, parochaid disappeared as a political issue.

Parochaid was lost in the courts only after it had succeeded in conventional electoral politics; desegregation was won in the courts only after it could not be attained through conventional electoral politics. Thus courts are critical to the ultimate success or failure of a policy initiative. But our focus here is less on the ultimate outcome of a policy initiative than on elements of the policy-making process that lead to the political success or failure of proposed policy changes.

Parochaid succeeded politically and desegregation failed politically not because the latter generated more opposition than the former. Both policies were deeply controversial. What distinguished the two cases was how political institutions structured the battles. In the case of desegregation, the institutional structure of shared educational responsibility required that local school boards--the actors that perceived themselves to be paying large costs and gaining few benefits--cooperate in developing and implementing the policy. It was easy for boards to resist and to use that resistance to pressure already ambivalent legislators. In the case of parochaid, the institutional structure of unitary responsiblity for the State budget required--and permitted--nothing of local school boards or citizens. The strongest opponents of the policy therefore possessed few institutional means to affect it, and their resistance was politically ineffective.

\section{THE POLITICAL SUCCESS OF SPECIAL EDUCATION}

The lesson of desegregation is that shared institutional responsibilities allow either partner to derail a controversial policy. But the case of special education shows that policies can be successfully developed and implemented within a divided political structure. Indeed, joint efforts by the SED and officials in Yonkers improved and sustained programs for children with handicapping conditions beyond what either partner could do alone. What distinguished this partnership from that of desegregation was agreement on goals for special education. Absent political controversy, New York's shared state-local institutional responsibilities for public education pose no barriers to success. 
Both New York State and local districts are responsible for ensuring that eligible children with handicapping conditions receive appropriate special education. To fulfill these responsibilities, Commissioners of the SED have promulgated extensive and detailed regulations (N.Y.C.R.R.). Districts must provide children with an education that conforms to these standards; the State must set the standards and ensure districts' conformity.

Districts submit extensive plans to the State to ensure that they meet the standards. Although the plans allow districts to set goals, create programs, and devise budgets, they must do so within parameters set by the State (N.Y.C.R.R.). The SED evaluates the districts' policies and plans and sends representatives to conduct on-site reviews. If reviewers find a district out of compliance, the State may withhold all state educational monies until the district can show that its programs meet the State's requirements. Although this rarely happens, the threat of losing funds gives districts, including Yonkers, a strong incentive to consult regularly with their educational partners in the SED to ensure compliance with the State's regulations.

From the 1960s through the mid-1980s, Yonkers' program in special education was plagued by an over-identification of black or Latino children and a stigmatizing effect on its participants (United States v. Yonkers, 1985). Beginning in 1972, Yonkers' Director of Special Education Gary Carmen sought to improve the quality of Yonkers' programs for children with handicapping conditions. Carmen installed himself as chair of the selection committee, instituted policies designed to "mainstream" the students into as many "regular" programs as possible, and assigned students to schools in their own quadrant of the district.

Working without assistance from the State, however, and facing principals and parents who resisted special education classrooms in their buildings, Carmen's initiatives had mixed results. Moreover, after he retired in 1975, his successor's less vigilant attention to race led to the reappearance of racial bias in assignments (United States v. Yonkers, 1985). Acting alone, educators in Yonkers could not effect enduring change in the policy.

In January 1979, the SED's Office for Education of Children with Handicapping Conditions (OECHC) conducted an on-site review of Yonkers' programs in special education. The reviewing team found the district woefully out of compliance with the State's educational regulations (New York State Education Department, 1979). Reviewers were also concerned that Yonkers had failed an inspection by the federal Office for Civil Rights (New York State Education Department, 1981). The latter failure was especially serious because the State could not receive its extensive federal funding for special education unless all districts satisfied federal requirements.

In contrast to its inaction regarding Yonkers' failure to desegregate, the State did not merely remind the District of its responsibilities. Instead, it informed the school board that Yonkers' implementation of corrective actions suggested by the SED "will be carefully monitored by the OECHC" (New York State Education Department, 1979). And monitor they did. The SED required the District to document its compliance with federal as well as with State regulations (Dodson, 1979). It worked with Yonkers' educators as they planned to reorganize their program and bring it into compliance. Indeed, in a follow-up audit in 1982, the review team credited the "supportive monitoring relationship between the district and the regional representative of the OECHC" as "the basis upon which the district dealt with the compliance issues cited in the 1979 OECHC report" (New York State Education Department, 1982).

Once the State stopped monitoring, however, the quality of the program lapsed. In 1987, the OECHC found the program out of compliance on over one hundred state mandates (New York State Education Department, 1987). This time when the SED stepped in to help, the OECHC and Susan LaDue, Yonkers' Director of Special Education, did not only work to bring the program into 
compliance. They also forged a more permanent alliance to enable them to prevent problems from developing (LaDue, 1991). This combined effort of state and local educators has led to careful attention when classifying black or Latino children for special education and to an end to segregation and stigmatization of the program's participants. Yonkers is now in full compliance with state and federal regulations.

Facilitating the State's and Yonkers' successful partnership was the fact that special education was not controversial. It did benefit a stigmatized group of students. But prejudice against the handicapped never rose to the level of the racism that intensified political opposition to desegregation or the anti-Catholic sentiment that fuelled opposition to parochaid. Furthermore, the State's involvement in special education was not redistributive. The State did spend some of its own monies on these programs, but the progrms also brought in large amounts of federal funding. Consequently, both the State and the District were free enough of the pressures created by political controversy that they could act as cooperative educational partners.

\section{CONCLUSION}

As these cases illustrate, the fact that a policy is controversial is not enough to explain its political failure. The fact that a policy requires cooperation from two institutional partners also does not suffice to explain political success or failure. But the combination of a high level of political controversy and the need for a high level of institutional cooperation is enough to predict the outcome of a policy initiative--it will fail in the arena of electoral politics (absent some extraordinary intervention).

What does this analysis imply for the political future of desegregation? Initially, our findings may deepen the pessimism of those who have heretofore seen political opposition as a sufficiently daunting barrier to desegregation. Now they must worry about institutional structure too. But the real lesson to draw from this analysis is that the outlook for desegregation may be more favorable than most assume. Even given citizens' opposition, state governments can succeed in desegregate schools if they can be insulated from local influence. After all, the case of parochaid showed that political controversy does not necessarily inhibit state policy-makers from taking strong action if they can act without fear of effective local resistance.

Thus the political failure of desegregation in New York was not inevitable. It occurred because localities were able to manipulate the State-local partnership in public education so as to render the State a silent partner. But if the school boards had lacked that option, if they had been forced to observe the policy process from the sidelines as was the case in parochaid, they arguably could not have translated opposition into a veto.

This conclusion implies that praise for New York's unusual structure for making educational policy is sometimes misplaced. The increasing involvement of the State in public education over the course of this century has rendered the State and local school boards mutually dependent partners. But mutual dependence can impede as well as promote action: Yonkers, at least, would have had more desegregation had either the SED or Yonkers' school board had complete control of all the resources necessary to achieve it. Given the degree of local opposition, and the strong commitment to desegregate on the part of two Commissioners, giving control to the State rather than to the locality would have been a better bet.

Arguing that educational authority over desegregation should reside solely with the State bureaucracy flies in the face of the currently fashionable advocacy of school decentralization (Clune et al., 1990). In the current educational and political climate, centralizing educational authority may 
seem infeasible. But recent proposals for national educational standards and teacher testing, among others, already support some such centralization. If educators are serious about pursuing school desegregation in their states, and if local resistance in racially imbalanced communities is to be expected, then the first step towards successful desegregation may well be governmental reform. After all, a powerboat will get you to the shore faster than a rowboat with only one oar in the water. 


\section{REFERENCES}

Allen directive hit by Malverne; Regents policy on rights lacking, attorney says. (1963, August 7). The New York Times, p. 21.

Boozer, M. A., Krueger, A. B., \& Wolkon, S. (1992). Race and school quality since Brown v. Board of Education. Brookings Papers on Economic Activity (Annual 1992, n. SPISS).

Washington, D.C.: Brookings Institution.

Brown v. Board of Education. (1954). 347 United States Reports 483.

Clark, K. (1988). [Deposition]. Yonkers v. The State of New York, 60 Civ. 6761 (LBS), S.D.N.Y., 14.

Clines, F. X. (1970, February 28). Regents support repeal of Blaine: Board, in 11-2 vote, backs aid for parochial schools. The New York Times, p. 3.

Clines, F. X. (1970, April 18) Church-pupil aid voted in Albany: \$28-million is appropriated-Governor favors bill. The New York Times, p. 16.

Clune, W. H., \& Witte, J. F. (Eds.). (1990). Choice and control in American education (Vols. 1-2). London: The Falmer Press.

Cooperative Institutional Research Program (1987). The American freshman: Twenty year trends,

1966-1985. Los Angeles: University of California, Los Angeles, Higher Education Research

Institute.

Cooperative Institutional Research Program (1992). The American freshman: National norms for fall 1992. Los Angeles: University of California, Los Angeles, Higher Education Research Institute.

Crain, R. L., \& Strauss, J. (1985). School desegregation and black occupational attainments: Results from a long-term experiment. Baltimore: Johns Hopkins University, Center for Social Organization of Schools.

Dodson, R. C. [Letter from Director of Special Services for Yonkers Public Schools to Hannah Flegenheimer] (1979, June 28). Unpublished document.

Dugan, G. (1972, April 29). Parochial pupils in demonstration: Court ruling barring aid is protested here. The New York Times, p. 36.

Farber, M. A. (1967, July 20). School board asks charter parley to keep ban on aid to parochial schools. The New York Times, p. 19.

Farrell, W. E. (1971, June 6). Albany approves \$33-million to aid parochial pupils. The New York Times, p. 1.

Farrell, W. E. (1972, January 12). Legislators firm on parochial school aid; G.O.P. leaders will press for plan to grant funds to nonpublic schools. The New York Times, p. 48.

Flast, F., \& Greenberg, L. (1968, February 27). Voters' rejection of Church-school aid [Letter to the editor]. The New York Times, p. 42.

Graham, F. P. (1971, June 29). High court, 8 to 1, forbids states to reimburse parochial schools; backs college-level help, 5 to 4 . The New York Times, p. 1.

Graham, F. P. (1972, October 11). Court, 8 to 1, bars Ohio tuition plan: Justices affirm invalidation of grants to parents of private school students. The New York Times, p. 20.

Greenhouse, L. (1974, April 12). Judge-race shift is voted for city. The New York Times, p. 29.

Greenhouse, L. (1992, April 1). Justices ease controls in school desegregation case. The New York Times, p. 1.

Guerney, J. (1990, November 1). Interview with Beth Lorenz, Steven Routh, and Monica Herk. Hacker, A. (1967, October 1). The 'Blaine Amendment'--Yes or No?. The New York Times, VI p. 27. 
Hochschild, J. L. (1984). The new American dilemma: Liberal democracy and school desegregation. New Haven: Yale University Press.

Jacobson, R. (1990, November 26). Interview by Jennifer Hochschild, Steven Routh, and Monica Herk.

Kihss, P. (1966, October 4). Lindsay seeking more home rule: Says mayors in state will unite for charter change. The New York Times, p. 1.

LaDue, S. (1991, July 2). Interview by Judith Failer and Monica Herk.

Lincoln Park Taxpayers Association Education Committee. (1977, March). Report. (Unpublished manuscript).

Lee v. Nyquist. (1970). 318 F.Supp. 710.

Lubasch, A. H. (1972, April 28). 3-judge panel bars aid by State for parochial school services. The New York Times, p. 15.

Lynn, F. (1970, December 31). Tactics changed in drive for parochial school aid. The New York Times, p. 1.

Lynn, F. (1971, January 26). Cooke relaxes stand on Blaine issue. The New York Times, p. 31.

Lynn, F. (1971, February 1). G.O.P. seeks to abandon support of Blaine repeal. The New York Times, p. 35.

Matter of Mitchell. (1963, June 17). Decision No. 7240, 2 Ed. Dept. Rep. 501.

Milstein, M. M., \& Jennings, R. E.. (1973). Educational policy-making and the state legislature: The New York experience. New York: Praeger Publishers.

Murphy, J. T. (1974). State education agencies and discretionary funds: Grease the squeaky wheel. Lexington, MA: D.C. Heath \& Co.

Narvaez, A. A. (1972, May 26). Governor signs school-aid bill: Nonpublic institutions could get \$56-million a year. The New York Times, p. 39.

New York Code of Rules and Regulations $\underline{8}$.

New York Constitution, Article 5, Section 4.

New York Education Laws 9 Sections 101, 215, 301, 305, 306, \& 3201(1).

New York State Education Department, Office for the Education of Children with Handicapping Conditions \& the Bureau of Bilingual Education. (1979, March 5). Site Visit Report of Yonkers Public Schools.

New York State Education Department, Office for the Education of Children with Handicapping Conditions. (1982, July 28). Site Visit Report of Yonkers Public Schools.

New York State Education Department, Office for the Education of Children with Handicapping Conditions. (1987). Site Visit Report of Yonkers Public Schools [review conducted between January and May, 1987].

Parochial school aid law in New York State stricken. (1976, June 22). The New York Times, p. 23.

Peterson, I. (1973, June 26). Church schools will stay open. The New York Times, p. 29.

Ronan, T. P. (1967, August 12). Two groups support school-aid ban: Parents and teachers join against Church-run units. The New York Times, p. 23.

Ronan, T. P. (1968, January 31). State Senate votes to end ban on Church-school aid; Repeal backed 35 to 17. The New York Times, p. 1.

Salvaging the good proposals [editorial]. (1967, November 13). The New York Times, p. 46.

Schanberg, S. H. (1967, November 8). Constitution beaten, transit bonds win; Jersey G.O.P. captures the legislature. The New York Times, p. 1.

Schanberg, S. H. (1967, November 9). Partisan fight shaping up on salvaging of charter. The New York Times, p. 1. 
Schanberg, S. H. (1968, January 3). Travia says he will not support Governor on tax increases. The New York Times, p. 1.

Schumach, M. (1967, April 29). Teachers giving pupils leaflets attacking parochial school aid. The New York Times, p. 24.

Sibley, J. (1972, October 3). U.S. court bans state aid to private-school parents. The New York Times, p. 1.

Spiegel, I. (1967, March 7). School-aid foes form state unit: Opponents to battle private use of Albany's funds. The New York Times, p. 49.

Spiegel, I. (1970, January 29). Orthodox rabbis back aid to religious schools. The New York Times, p. 27.

Spiegel, I. (1970, June 22). Governor, 2 rivals help dedicate Hasidic center. The New York Times, p. 40.

Sutton and Cardino clash on school aid. (1967, June 30). The New York Times, p. 33.

Taxpayers Organization of North East Yonkers Education Committee. (1978, March). TONEY report on "School Reorganization Phase \#2". (Unpublished manuscript).

United States v. Yonkers Board of Education. (1985). 624 F. Supp. 1276.

University of the State of New York. (1960, January 27-28). Regents statement on intercultural relations in education. Journal of Regents Meeting. New York: The University of the State of New York.

Usdan, M. D. (1963). The political power of education in New York State. New York: Institute of Administrative Research, Teachers College, Columbia University.

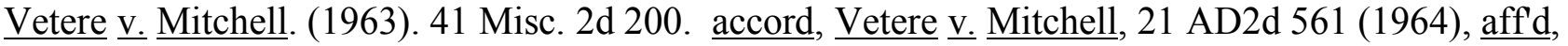
15 N.Y.2d 259 (1965), cert. denied, 382 U.S. 825 (1965).

Wilson, J. Q. (1974). The politics of regulation. In McKie, J. W. (Ed.). Social responsibility and the business predicament (pp. 135-68). Washington, D.C: Brookings Institution. 